\title{
Author byline (Culture Coverage)
}

\section{AUTHOR}

Maarit Jaakkola

\section{KEYWORDS}

cultural coverage, cultural journalism, authorship, freelancers, outsourced production

\section{BRIEF DESCRIPTION OF THE VARIABLE}

This variable describes the employment basis that the writers of the articles represent. It distinguishes between staff writers, representing in-house newsroom production, and freelancerbased writers, representing outsourced production. It also examines the shares of non-signed and news agency material, as well as material produced by the audience, whenever it is placed on culture pages. These are the major production instances for cultural coverage. Tracing their development across time delivers information on the strategic and economic shifts, reflected in the use of non-specialized writers (journalists from other departments and outsourced production).

FIELD OF APPLICATION/THEORETICAL FOUNDATION As debates on the state of cultural journalism and the anatomy of cultural coverage are often centered around the volume of reviews, this variable delivers more detailed information about the production structures of the articles. Commissioning freelancers is specifically characteristic of cultural coverage; in cultural journalism, ex- ternal authors are used more than in any other form of journalism. Through the variable, it can be examined to which extent the freelancer networks are being used for cultural coverage. Another prevalent question for cultural coverage is the extent of news agency material, or "churnalism" (Kristensen, 2018), which strengthens the ties of cultural coverage to cultural industry and, as an indication of less critical distance, is regarded as non-preferable.

\section{REFERENCES/COMBINATION WITH OTHER METHODS OF DATA COLLECTION}

In coding the variable, the author name indicated in the byline is recorded. The variable typically needs background research for determining individual authors' employment contracts, which may also vary from time to time. For distinguishing between specialized staff journalists, general staff journalists, and freelancer journalists, the researcher may utilize newsroom superiors as informants, as well as the authors themselves. When cross-tabulated with other variables, the variable provides useful information on how freelancer production has developed in time with regard to cultural forms, genres, and gender.

\section{SAMPLE OPERATIONALIZATION}

The author byline is operationalized as follows: see Table 1

Table 1. Operationalization.

Event type

Specialized staff journalist
Description

Cultural journalist: salary-based staff journalist in the culture department 


\begin{tabular}{ll} 
Event type & Description \\
\hline General staff journalist & $\begin{array}{l}\text { Other journalist: salary-based staff journalist in a department } \\
\text { other than culture }\end{array}$ \\
\hline Freelancer journalist & $\begin{array}{l}\text { Outsourced production: writer separately commissioned for the } \\
\text { text }\end{array}$ \\
\hline Newsroom signature & $\begin{array}{l}\text { Byline referring to the newspaper in question, leaving the writer } \\
\text { anonymous }\end{array}$ \\
\hline News agency & Name of the news agency (AFP, AP, Reuters, etc.) \\
\hline Member of audience & A reader, non-journalist \\
\hline Not recognizable & Producer of the text unknown, not signed \\
\hline
\end{tabular}

\section{EXAMPLE STUDY}

Jaakkola (2015)

\section{INFORMATION ABOUR JAAKKOLA, 2015}

Author: Maarit Jaakkola

Research question/research interest: Representation of the author bylines according to the work contract of the journalists on culture pages of daily newspapers across time, to expose the production structure

Object of analysis: Articles/text items on culture pages of five major daily newspapers in Finland 1978-2008 (Aamulehti, Helsingin Sanomat, Kaleva, Savon Sanomat, Turun Sanomat)

Timeframe of analysis: 1978-2008, consecutive sample of weeks 7 and 42 in five year intervals (1978, 1983, 1988, 1993, 1998, 2003, 2008)

\section{INFO ABOUT VARIABLE}

Variable name/definition: Author Unit of analysis: Article

Values: 1 = specialized staff journalist, $2=$ general staff journalist, $3=$ freelancer journalist, $4=$ newsroom signature, $5=$ news agency, $6=$ member of the audience, $7=$ not recognizable

Scale: nominal

Intercoder reliability: Cohen's kappa $>0.76$ (two coders)

\section{REFERENCES}

Jaakkola, M. (2015). Outsourcing views, developing news: Changes of art criticism in Finnish dailies, 1978-2008. Journalism Studies, 16(3), 383-402. https://doi. org/10.1080/1461670X.2014.892727

Kristensen, N.N. (2018). Churnalism, cultural (inter)mediation and sourcing in cultural journalism. Journalism Studies, 19(14), 2168-2186. 